\title{
CULTURE AS CONTINUUM: WALTER PATER'S DIONYSUS IN EXILE AND THE POWER OF EKPHRASIS ${ }^{1}$
}

\begin{abstract}
Over the last decades scholars of Victorian literature, modernism, gender and art history have investigated Walter Pater's complex literary texts and essays from new angles. Due to the intense cross-cultural, intermedial and interdisciplinary nature of his work Pater is still a topical writer. Against the backdrop of current academic debates on intermediality, transculturality, cultural memory, 'biofiction' and the construction of classical antiquity this article readdresses Pater as an ekphrastic writer and innovative historian of culture. His imaginary portrait "Denys l'Auxerrois" is read as a comparative, transcultural and transhistorical narrative which allowed Pater to transgress disciplinary boundaries, to experiment with the Victorian genre rules, to fathom the relationships of the media and to contribute significantly to historiography.
\end{abstract}

\section{INTRODUCTION}

As Ben de Bruyn and others in Kelly Comfort's recent collection of essays Art and Life in Aestheticism ${ }^{2}$ demonstrate, after a long period of neglect, recent decades have witnessed a resurgence in critical interest with regard to nineteenth-century Aestheticism which has led to a reevaluation of its seminal literary works. ${ }^{3}$ Walter Pater (1839-1894) was a leading Victorian writer, scholar, literary critic and art historian with a considerable impact on this notorious fin de siècle period. While Pater has always incarnated the aesthete per se, he is now often discussed as a transitional figure who paved the way for literary modernism and whose work contributes to ethical and moral debates. He became famous, if not notorious when his first collection of essays, The Renaissance. Studies in Art and Poetry, ${ }^{4}$ was published in 1873. Due to its homoerotic undercurrent and its advocacy of hedonism and atheism, tendencies late Victorian society tried to suppress with greater or lesser success, The Renaissance caused a scandal

1 This article is dedicated to Erika Greber, an outstanding literary scholar and dear friend, who died on 31 July 2011.

${ }^{2}$ Kelly Comfort, ed. Art and Life in Aestheticism: De-Humanizing and Re-Humanizing Art, the Artist, and the Artistic Receptor (Houndmills: Palgrave Macmillan, 2008).

3 Cf. Ben de Bruyn, “Art for Heart's Sake: The Aesthetic Existences of Kierkegaard, Pater, and Iser", in Comfort 2008, 208-231.

4 Walter Pater, The Renaissance: Studies in Art and Poetry (Oxford: Oxford UP, 1986). 
both within the university and beyond. Pater favoured an elaborate mannerist style of writing in order to achieve a constant burning with a "hard, gem-like flame, to maintain ... [life's] ecstasy". ${ }^{5}$ It was his creed that the search for ecstasy and wisdom in its most intense form is deeply rooted in all human beings and that in his own time ecstasy and wisdom are best found in "the poetic passion, the desire of beauty, the love of art for its own sake" ${ }^{6}$ According to Pater it is autonomous and aestheticist art that helps modern man to heighten and intensify life in which "the desire of beauty [is] quickened by the sense of death". ${ }^{7}$ What makes Pater so astonishingly modern is that in contrast to earlier attempts to define beauty as an abstract, universal or objective formula, Pater in his "Preface" to The Renaissance points out the "relative" 8 and subjective character of beauty. For him, the beautiful depends on the individual beholding it, on his or her impressions and the pleasure these impressions produce. ${ }^{9}$ However, the individual's impressions are in constant flux ${ }^{10}$ and the cohesive force of the individual

... seems suspended like some trick of magic; each object is loosed into a group of impressions - colour, odour, texture - in the mind of the observer. And if we continue to dwell in thought on this world, not of objects in the solidity with which language invests them, but of impressions, unstable, flickering, inconsistent, which burn and are extinguished with our consciousness of them, it contracts still further: the whole scope of observation is dwarfed into the narrow chamber of the individual mind. Experience, already reduced to a group of impressions, is ringed round for each one of us by that thick wall of personality through which no real voice has ever pierced on its way to us, or from us to that which we can only conjecture to be without. Every one of those impressions is the impression of the individual in his isolation, each mind keeping as a solitary prisoner its own dream of a world. ${ }^{11}$

5 Pater, Renaissance 152.

6 Pater, Renaissance 153.

7 Walter Pater, "Aesthetic Poetry", Walter Pater. Essays in Literature and Art. Ed. Jennifer Uglow (London: Dent-Totowa, 1973) 95-102, at 102. "Aesthetic Poetry" was first published in Appreciations. With an Essay on Style in 1889 as part of the essay "Poems by William Morris", in Walter Pater, Appreciations. $2^{\text {nd }}$ ed. (London: Macmillan, 1920) 241-261.

8 Pater, Renaissance XXIX.

9 Pater, Renaissance XXX.

${ }^{10}$ It is not surprising that the motto of the "Conclusion" is a quotation from Heraclitus: "All things are in motion and nothing at rest" (Pater, Renaissance 150). Pater's own translation of Heraclitus' sentence in his Plato and Platonism was: “All things give way: nothing remaineth" (Edinburgh: R. \& R. Clark, 1893) 9. For a discussion of Pater's idea of flux cf. Martin Middeke, "Zur Poetologie gelebter Zeit im spätviktorianichen Roman”, Zeit und Roman. Ed. Martin Middeke (Würzburg: Königshausen \& Neumann, 2002) 161-195.

11 Pater, Renaissance 151. 
All human impressions and worldly things are transitory, incoherent and unstable. Even the individual is isolated and fragmented, and thus no longer able to experience itself in a unitary way. The subject turns out to be a prisoner of his or her own solipsistic impressions, dream images and illusions. Pater's ideas about the atomization of the world, about relativism and the fragmentation of the subject characterise him as one of the most important forerunners of English modernism, ${ }^{12}$ who influenced writers and poets as diverse as William Butler Yeats, Henry James, Hilda Doolittle, T. S. Eliot, James Joyce and Virginia Woolf - even if many of them denied any indebtedness. ${ }^{13}$

Pater wrote at a time of radical change and social upheaval, a time when traditional values and beliefs lost their validity and apocalyptic fears concerning death and the decline of (national) culture gained in influence. Revolutionary new developments in geology, archaeology, ethnography and mythography as well as new technical and economic advances led to what Max Weber has called the disenchantment of the world. It was also the time when the invention of photography in the first half of the century resulted in deluges of mechanically re/produced pictures becoming a common feature of everyday life. Apart from reading Pater as a seminal late nineteenth-century author and towering figure of late Victorian intellectual life who decisively influenced modernism, this article will readdress Pater as an intermedial and ekphrastic writer and historian of culture. Also, a reading of Pater's texts in the context of current academic debates on the concept of transculturality enables us to trace its historical roots. Wolfgang Welsch has contrasted transculturality with the classical separatory, particularistic concept of single cultures and with the more recent concepts of interculturality and multiculturality, which still originate in, and thus barely transcend, the traditional conception of cultural particularism. ${ }^{14}$

12 Cf. Wolfgang Iser, Walter Pater. Die Autonomie des Ästhetischen (Tübingen: Niemeyer, 1960) 179f. See also Wolfgang Iser, "Walter Pater und T. S. Eliot. Der Übergang zur Modernität”, Germanisch-Romanische Monatsschrift 9 (1959): 391-408.

13 Gerald Monsman, "Pater and His Younger Contemporaries", The Victorian Newsletter 48 (1975): 1-9, at 1. Cf. also Perry Meisel, The Absent Father: Virginia Woolf and Walter Pater (New Haven: Yale UP, 1980). Especially Woolf's notion of "moments of being" and the portrayal of the human mind in her famous 1919 essay "Modern Fiction" as receiving "a myriad impressions" demonstrate clearly her indebtedness to Pater (I. Woolf, "Modern Fiction", The Common Reader [London: Hogarth P, 1984] 146-154, at 150). Lesley Higgins has recently investigated in great detail the indebtedness of the male modernists to Pater ("No Time for Pater: The Silenced Other of Masculinist Modernism", Walter Pater. Transparencies of Desire. Ed. Laurel Brake, Lesley Higgins \& Carolyn Williams [Greensboro: ELT P, 2002] 37-54).

14 Wolfgang Welsch, "Transculturality: The Puzzling Form of Cultures today", Spaces of Culture: City, Nation, World. Ed. Mike Featherstone \& Scott Lash (London: Sage, 1999) 194-213. Welsch maintains "the description of today's 
While cultural hybridization is a central feature of today's version of transculturality, Pater already ascribed this quality to earlier periods, for instance in his discussions of artistic and architectural styles which developed "across countries and nations". ${ }^{15}$ Today's debates on transculturality, cosmopolitanism and the relation of global and local factors question the nineteenth-century "imaginary notion of homogeneous national cultures" ${ }^{16}$ Walter Pater's work, for instance his imaginary portraits, did this right from the start and are hence prime examples of historical transcultural narratives which add significantly to our academic debates. Pater's comparative, transcultural and transhistorical approach, his transgression of disciplinary boundaries, his experiments in genre (what is now often called 'biofiction') and historiography as well as the intermedial quality of his texts testify to the topicality of his work.

\section{Culture as Continuum: \\ “THE SPRINGING OF VIOLETS FROM THE GRAVE"17}

Within the context of nineteenth-century culture Pater developed his concepts of 'tradition' and of 'collective' and 'cultural memory', terms which have become leading concepts in the humanities over the last decades. Pater saw himself as a melancholy, mournful 'late age' artist-scholar ${ }^{18}$ who is full of reminiscences of forgotten cultures. Artist-scholars have a "wistfulness of mind"19 and live completely in and from the memory of cultural heritage which they try to keep alive. Critical receptivity, the critical evaluation of the cultural heritage, is the literary activity of a late age, ${ }^{20}$

cultures as island or spheres is factually incorrect and normatively deceptive. Cultures de facto no longer have the insinuated form of homogeneity and separateness. They have instead assumed a new form, which is to be called transcultural in so far as it passes through classical cultural boundaries" (197).

15 Welsch 1999, 200. According to Welsch, historical transculturality becomes particularly evident in European history and art history: "Styles developed across the countries and nations, and many artists created their best works far from home. The cultural trends were largely European and shaped a network linking the states" (200).

16 Welsch 1999, 199.

17 Pater, Renaissance 150.

18 In his famous essay on "Style" (appeared in Fortnightly Review in December 1888 and was reprinted 1889 in Appreciations), Pater points out that: "The literary artist is of necessity a scholar ... For the material in which he works is no more a creation of his own than the sculptor's marble" (12).

19 Pater, Renaissance 156.

20 Walter Pater, "Romanticism." (Appeared in Macmillan's Magazine in November 1876 and was reprinted 1889 in Appreciations under the title "Postscript.") 
when to write means to remember, and not to create. ${ }^{21}$ Pater always tried to relate the past to the present and believed strongly in transhistorical continuity. But he was neither a historicist nor an antiquarian. In his essay on "Aesthetic Poetry" Pater pointed out with respect to the reception of classical antiquity that: "[i]n handling a subject of Greek legend, anything in the way of an actual revival must always be impossible. Such vain antiquarianism is a waste of the poet's power". ${ }^{22}$ Pater was not so much interested in precise historical research and facts, but rather aimed at creating suggestive intellectual atmospheres and aesthetic impressions of former times. Not surprisingly, eclecticism and syncretism were Pater's stylistic ideals. $^{23}$ His language is heterogeneous and his texts are patchworks of digressions, allusions, puns and quotations, a quality which has been referred to as a "poetics of reminiscence". ${ }^{24}$ They are fine examples of intertextual, intermedial and intercultural 'translations' which mix languages, cultures, discourses, aesthetic categories and literary genres. ${ }^{25}$ This cross- $^{2}$ ing of disciplinary boundaries which is found in all his works invites his readers to draw connections between his texts and the visual arts, to tapestry, sculpture, photography and cinema, but also to music, the theatre, evolutionary anthropology, classical studies, comparative philology and

21 Imaginative memory is replacing the creative faculty of the literary genius (which has been responsible for composing literary texts ever since Romanticism; cf. Claus Uhlig, "Walter Pater und die Poetik der Reminiszenz", Poetica 6 [1974]: 205-277, at 210). Understanding and categorising of what is already there transform the poet into a scholar who is versed in complex eclecticism. The adequate medium for a late, and consequently complex and eclectic epoch is imaginative prose. As poetry - says Pater in reference to Hegel's Aesthetics belongs to the early days of mankind's mental development, and the sternness of a treatise was adequate for medieval scholasticism, the essay is "that literary type of our own time, a time so rich and various in special apprehensions of truth, so tentative and dubious in its sense of their 'ensemble', and 'issues" (Plato and Platonism 174).

22 Pater, "Aesthetic Poetry" 100. In his imaginary portrait "Duke Carl of Rosenmold" he points out: "Surely, past ages, could one get at the historic soul of them, were not dead but living, rich in company, for the entertainment, the expansion, of the present ..." $(1887,98)$, and in his unfinished novel Gaston de Latour Pater writes: "It was the power of 'modernity', as renewed in every successive age for genial youth, protesting, defiant of all sanction in these matters, that the true 'classic' must be of the present, the force and patience of present time" $(1888,137)$.

23 Pater, "Style".

24 Cf. Uhlig 1974, 210.

25 Cf. Ulla Haselstein, "Et in Arcadia Ego. Walter Paters Gedächtniskonzept”, Gedächtniskunst: Raum - Bild - Schrift. Studien zur Mnemotechnik. Ed. Anselm Haverkamp \& Renate Lachmann (Frankfurt am Main: Suhrkamp, 1991) 263294. 
mythography, philosophy and Victorian sexual politics, hence to read his texts against their historical, cultural and medial background. ${ }^{26}$

Within the frame of his notion of culture as continuum, Pater interpreted central cultural forms such as rites, myth, religion and art as manifestations of a transhistorical and transcultural anthropological fact, man's fear and mourning in view of the certainty of death:

This pagan sentiment measures the sadness with which the human mind is filled, whenever its thoughts wander far from what is here, and now. ... He [man, G. R.] makes gods in his own image, gods smiling and flower-crowned, or bleeding by some sad fatality, to console him by their wounds, never closed from generation to generation. It is with a rush of home-sickness that the thought of death presents itself. He would remain at home for ever on the earth if he could. ... but since the mouldering of bones and flesh must go on to the end, he is careful for charms and talismans, which may chance to have some friendly power in them, when the inevitable shipwreck comes. Such sentiment is a part of the eternal basis of all religions, modified indeed by changes of time and place, but indestructible, because its root is so deep in the earth of man's nature. ${ }^{27}$

Knowledge of the inevitability of death is the force behind all rituals and cultural achievements, and art the human answer to death. Whereas the serenity of Greek sculptures served to harmonise the central anthropological conflict, later works of art express fear and mourning more directly. ${ }^{28}$ For Pater, Greek antiquity and Christian medieval times are marked by defensive mechanisms against the knowledge of death, but by opposite means: Whereas Greek art celebrates the beautiful human body by posing the marmoreal duplicate against its decayed form, Christianity tries to overcome death by declaring the immortality of the soul and the mere mortality of the body. Pater's emphasis on intense experience, on ecstasy and on beauty is a symptom of his obsession with death. Human life is splendid, but the knowledge about its "awful brevity", 29 the awareness that "we all are under sentence of death" 30 must lead to an intense tasting of the passing moments of being. ${ }^{31}$ As only art can create continuity in a world doomed by temporality and transitoriness, Pater has highest rever-

${ }^{26}$ Cf. Elicia Clements \& Lesley J. Higgins, "Introduction. The Aesthetic Life: Thinking Across the Arts and the Senses", Victorian Aesthetic Conditions. Pater Across the Arts. Ed. Clements \& Higgins (Houndmills: Palgrave Macmillan, 2010) 1-10.

27 Pater, Renaissance 129. Pater sees ritual as the common basis of all religions, including those of Greece and the Middle Ages. Ritual with its structures of repetition and order helps to create stability in an extremely insecure world.

28 Pater is following Hegel, when he points out that architecture is the art of ancient Egypt, sculpture the art of ancient Greece and painting, music and poetry the art of romantic and modern times (Renaissance 135).

29 Pater, Renaissance 152.

30 Pater, Renaissance 153.

31 "Only passions - preferably those aroused by art - can momentarily cover the pain of finiteness by capturing the intensity of the passing moment." Wolfgang 
ence for cultural artifacts. ${ }^{32}$ In his essay on "Leonardo da Vinci" 33 Pater delivers a description of Leonardo's late painting “Mona Lisa” (1503). Under his melancholic gaze of a late age beholder, Mona Lisa and her unfathomable smile turn into a condensed metaphor for Pater's concept of culture and cultural memory:

Here is the head upon which all 'the ends of the world are come', ${ }^{34}$ and the eyelids are a little weary. It is a beauty wrought out from within upon the flesh, the deposit, little cell by cell, of strange thoughts and fantastic reveries and exquisite passions. Set it for a moment beside one of those white Greek goddesses or beautiful women of antiquity, and how would they be troubled by this beauty, into which the soul with all its maladies has passed! All the thoughts and experience of the world have etched and moulded there, in that which they have of power to refine and make expressive the outward form, the animalism of Greece, the lust of Rome, the mysticism of the middle age with its spiritual ambition and imaginative loves, the return of the Pagan world, the sins of the Borgias. She is older than the rocks among which she sits; like a vampire, she has been dead many times, and learned the secrets of the grave; and has been a diver in deep seas, and keeps their fallen day about her; and trafficked for strange webs with Eastern merchants; and, as Leda, was the mother of Helen of Troy, and, as Saint Anne, the mother of Mary; and all this has been to her but as the sound of lyres and flutes, and lives only in the delicacy with which it has moulded the changing lineaments, and tinged the eyelids and the hands. The fancy of a perpetual life, sweeping together ten thousand experiences, in an old one; and modern philosophy has conceived the idea of humanity as wrought upon by, and summing up in itself, all modes of thought and life. Certainly Lady Lisa might stand as the embodiment of the old fancy, the symbol of the modern idea. ${ }^{35}$

Pater's description of Leonardo's painting is an ekphrasis, a rhetorical exercise and genre handed down from classical antiquity (cf. below part III), which has received a huge amount of scholarly attention over the last three decades. ${ }^{36}$ What is interesting, however, about Pater's ekphrastic de-

Iser, Walter Pater. The Aesthetic Moment. Trans. David Henry Wilson (Cambridge: Cambridge UP, 1987) 30.

32 "As a prophet of art, Pater has the highest reverence for cultural artifacts.... Works [of art] are invested with a semi-religious aura and consecrated as objects for reverence with a perpetual abode in the cultural memory." Aleida Assmann, "From the End of the World to the Fin de Siecle. Obsession with Endings in Texts of Sir Thomas Browne and Walter Pater", Anglistentag 2000 Berlin: Proceedings. Ed. Peter Lucko \& Jürgen Schlaeger (Trier: WVT, 2001) 205-215, at 214.

33 Pater, Renaissance 63-82.

34 Cf. I Corinthians $10 f$.

35 Pater, Renaissance 80. Italics G.R.

36 This is reflected in the numerous book-length studies published on this topic, for instance Mario Klarer's Ekphrasis: Bildbeschreibung als Repräsentationstheorie bei Spenser, Sidney, Lyly und Shakespeare (Tübingen: Niemeyer, 2001); Murray Krieger's Ekphrasis: The Illusion of the Natural Sign (Baltimore: Johns Hopkins 
scription of Leonardo's Mona Lisa is that it does not care too much for enargeia ('Anschaulichkeit'), i.e. it does not aim at giving a verbal equivalent and exact representation of what can be seen in the precious painting. According to Angela Leighton, it in fact

... takes the painting out of the gallery and loads it with unlikely contextual references. ... What passes through the picture is a movie of history, and of history presented as transient and relative. Pater is less concerned with the art work for art's sake than with the ways in which it might express a passing panorama of time, with all creeds, moralities and myths reduced to an egalitarian flux. ... The way that Pater reads the Mona Lisa almost unframes it altogether, leaving no dividing line between the work of art and the swimmingly impressionistic memories it inspires. ${ }^{37}$

Clearly, Pater's ekphrasis is not so much interested in delivering a meticulous description of the painting, but rather in dispersing meaning, in producing an intense atmosphere and in offering associations. Pater's description of Leonardo's Gioconda as a palimpsest reads like a photographic or filmic metaphor for superimposing pictures and employing dissolving techniques. As a result, the painting can no longer be read as a mere portrait of an individual, i.e. in a referential way, but is instead turned into an 'imaginary' portrait. This "rejection of documentary realism" together with "the cyclical nature of history" enables Pater to intertwine "cultures which are distant from each other in time but which reveal affinities in mood". ${ }^{38}$ In the first few sentences of the italicised passage in the quote from Pater's Leonardo essay, Mona Lisa is described as "older than the rocks among which she sits", she is a vampire, a Wiedergänger, a revenant $^{39}$ who has been dead many times and therefore knows the secrets of the grave and of depth, but has also the vital occult potential to be resurrected any time. ${ }^{40}$ Thus she becomes a symbol of the powers of rebirth,

UP, 1992); James A. W. Heffernan's Museum of Words. The Poetics of Ekphrasis from Homer to Ashbery (Chicago: U of Chicago P, 1993); and Gabriele Rippl's Beschreibungs-Kunst. Zur intermedialen Poetik angloamerikanischer Ikontexte (1880-2000) (München: Fink, 2005). Cf. also Beschreibungskunst Kunstbeschreibung. Ekphrasis von der Antike bis zur Gegenwart. Ed. Gottfried Boehm \& Helmut Pfotenhauer (München: Fink, 1995).

37 Angela Leighton, “Aesthetic Conditions: Returning to Pater”, in Brake, Higgins \& Williams 2002, 12-23, at 16f.

38 Maurizio Ascari, “The Mask without the Face: Walter Pater's Imaginary Portraits", Textus 12 (1999): 97-112, at 101.

39 Cf. Andrew Eastham, "Aesthetic Vampirism: Pater, Wilde, and the Concept of Irony" (in Comfort 2008, 79-95), who focuses on the vampire features of La Gioconda. Eastham suggests reading Pater's imaginary portrait "Denys L'Auxerrois" also as a vampire narrative.

40 For Pater Mona Lisa's creator, Leonardo, is a genius exactly because he was in control of "the art of going deep" (Renaissance 66); he was a "sorcerer" and "magician" who possessed "curious secrets and a hidden knowledge" (Renaissance 68). 
for the conquest of oblivion. ${ }^{41}$ The next sentences locate Mona Lisa as a historical figure in ancient myth and in Christianity. She is the storehouse of past times and assembles all historical epochs, antiquity, the Middle Age, the Renaissance and Pater's own late age; the lady's weary eyelids symbolise her eternal, simultaneous presence. Only the last two lines deliver a rather concise description of Leonardo's delicate painting technique, which keeps history and former cultures alive in our cultural archive and helps to intensify aesthetically the facts of life. Only art allows for a perpetual recurrence and reanimation of whatever has been of human concern. ${ }^{42}$ Pater's (male) gaze and (male) verbal ekphrastic art turns Leonardo's Mona Lisa, which assembles many images in one, into a palimpsest of the cultural unconsciousness of the Western world (conceived as female) which embraces all former epochs and cultures. Just like an individual memory, this cultural memory of mankind has stored layers ${ }^{43}$ of epochs and cultures in the "House Beautiful" as Pater calls the cultural storehouse. ${ }^{44}$ Mona Lisa's countenance and her enigmatic smile mirror the accumulated reminiscences of former cultures as riddles and mysteries which have to be deciphered by a susceptible onlooker. ${ }^{45}$ Pater's ekphrasis

41 Pater expresses the missing memory and consciousness in Greek goddesses, which contrasts with Mona Lisa's impossibility to forget, by the adjective "white". For a discussion of cultural memory cf. Aleida Assmann, Erinnerungsräume. Formen und Wandlungen des kulturellen Gedächtnisses (München: C. H. Beck, 1999) esp. 229-240.

42 Iser 1987, 46. Cf. also Carolyn Williams, Transfigured World, Walter Pater's Aesthetic Historicism (Ithaca: Cornell UP, 1989) 111-123.

43 Pater's notion of culture consisting of different layers to be activated by a prophetic artist-scholar probably goes back to Thomas de Quincey's (1785-1859) famous concept of the human brain as palimpsest, "a membrane or roll cleansed of its manuscript by reiterated successions" ("The Palimpsest of the Human Brain”, Essays. Suspiria de Profundis [De Quincey, 1845] 265-276, at 265).

44 This term aligns him with the long tradition of memoria theoreticians using spatial metaphors for demonstrating their notions of memory (e.g. theatre of memory). For the metaphors used in the memoria discourses cf. Aleida Assmann, "Zur Metaphorik der Erinnerung”, Gedächtnis und Erinnerung. Mannheimer Forum 97/98. Ed. Ernst Peter Fischer (München: Piper, 1998) 111-164. The inheritors of a tradition who try to understand the literary and cultural treasures will always find them in "that House Beautiful, which creative minds of all generations ... are always building together, for the refreshment of the human spirit" (Walter Pater, "Postscript", Appreciations 241-261, at 241). Pater believed "[t]hat nothing which had ever interested the human mind could wholly lose its vitality" and in this he sees "the essence of humanism" (Renaissance 32).

45 Just like Medusa and Salomé, Mona Lisa's air of mystery fascinated the late Victorians. Pater even saw in Leonardo's different depictions of Medusas precursors of the Mona Lisa, whose amorphous structure mirrors the dialectics of corruption, terror and beauty of the Medusa of the Uffizii ("the fascination of corruption penetrates in every touch its exquisitely finished beauty" [Renaissance 68]). 
of the Mona Lisa demonstrates that for him creation is never sudden, abrupt and ex nibilo, but a cumulative series of rebirths. This is why Pater defined culture as "the springing of violets from the grave". ${ }^{46}$ Pater's belief in continuity to be the main feature of culture is shared by another art historian and theoretician of culture, namely Aby Warburg, who developed a painstakingly scholarly research approach to culture a few decades after Pater's death. Warburg's scientific method, however, deviates drastically from the prophetic approach of Pater's susceptible scholar-artist.

\section{Ekphrastic Strategies in Pater's Mythopoetical IMAginary Portrait “Denys L'AuXerrois"}

Maurizio Ascari maintains “... Pater turns history into a succession of imaginary portraits, of fictional biographies, of narrations whose balance is always precarious". ${ }^{47}$ We have called Pater's description of the Mona Lisa an imaginary portrait and will now discuss this genre in more detail. The imaginary portrait is "outside the generic categories of Victorian literature" ${ }^{48}$ it was in fact the result of Pater's experiments in fiction and historiography and "lies at the intersection of autobiography, biography, the short-story, myth, the history of art, of ideas, of manners, of events". ${ }^{49}$ How much Pater appreciated the imaginary portrait can be detected from the fact that even his essays, for instance those collected in The Renaissance, as well as his other fiction often take on the character of portraits. ${ }^{50}$ Art history defines a 'portrait proper', which has its roots in antiquity, as a picture of a person: "Simply put, portraits are art works, intentionally made of living or once living people by artists, in a variety of media, and for an audience". ${ }^{51}$ According to Wendy Steiner the portrait is a curious bastard of art, as it is "both a work of art and a document",

46 Pater, Renaissance 150.

47 Ascari 1999, 111.

48 Imaginary portraits are characterised by a diminished plot emphasis and "may be considered forerunners of one of the major developments of twentieth-century literature, the 'psychological novel' with its stress on the rendering of impressions, on characters and point of view" (Monsman 1975, 5). Cf. also Elisa Bizzotto, "The Imaginary Portrait: Pater's Contribution to a Literary Genre", in Brake, Higgins \& Williams 2002, 213-223.

49 Ascari 1999, 98.

50 Pater was heavily criticised for not holding on more tightly to historical facts. T. S. Eliot dismissed Pater as "morbid" and accused him of confusing art and life in the portraits of The Renaissance which he called "untidy lives." T. S. Eliot, "Arnold and Pater", Selected Essays (London: Faber \& Faber, 1963) 431-443, at 442. But as Pater never claimed to pursue historical truth and instead made it clear that what really interested him are condensed aesthetic and intellectual atmospheres, which convey the Zeitgeist of a certain age, Eliot's criticism is not wholly justified. 
following "two different and normally antagonistic sets of norms - the aesthetic and the specifically referential". 52 Due to the fact that Pater's imaginary portraits are hybrid forms, playing "biografictional games", Max Saunders has called Pater's concept of a portrait which uses lifewriting forms for fictional purposes "especially paradoxical". ${ }^{53}$ They are "works which take the form of the portrait, but free it from the chains of referentiality". 54 Portraits are generically unstable combinations, precisely because Pater

... fuses forms traditionally valued for their truth-telling - portraiture, history, essay, biography, autobiography - with the counter-factual energies of fiction, imagination, and myth. His experiments were not unprecedented. But what has not been appreciated is how his achievements in the Imaginary Portraits are as much a matter of form as of content. ... He also engages with the authority of the forms of auto/biography or history, fusing them with the forms of fiction and criticism. It is in this transformative engagement with the forms of life-writing that much of his originality lies. ${ }^{55}$

According to Saunders, Pater's imaginary portraits paved the way "for modernist and postmodern thought about self-representation". 56 The increased usage of the term 'portrait', which after the mid-nineteenth century frequently displaced the established terms "'The Life of', 'Memoirs of', 'The Adventures of"" 57 and continued to do so well into the twentieth,

51 Richard Brilliant, Portraiture (London: Reaktions Books, 1991) 8. He continues, 10f: "Most portraits exhibit a formal stillness, a heightened degree of self-composture that responds to the formality of the portrait-making situation. Either the sitter composes himself, or the portraitist does it to indicate the solemnity of the occasion and the timelessness of the portrait image as general, often generous statement, summing up 'a life'. ... Portraits exist at the interface between art and social life and the pressure to conform to social norms enters into their composition because both the artist and the subject are enmeshed in the value system of their society."

52 Wendy Steiner, Exact Resemblance to Exact Resemblance (New Haven: Yale UP, 1978) 1 and 4, where she refers to Vernon Lee. Like Steiner, Jules Lubbock sees the main function of portraiture in its immediacy. Cf. Jules Lubbock, "Walter Pater's Marius the Epicurean - The Imaginary Portrait as Cultural History", Journal of the Warburg and Courtauld Institutes 46 (1983): 166-190.

53 Max Saunders, “Im/personality: The Imaginary Portraits of Walter Pater", Self Impression: Life-Writing, Autobiografiction, and the Forms of Modern Literature (Oxford: Oxford UP, 2010) 29-70, at 40.

54 Saunders 2010, $39 \mathrm{f}$.

55 Saunders 2010, 42.

56 Saunders 2010, 70.

57 Norman Kelvin, "The Painting as Physical Object in a Verbal Portrait: Pater's 'A Prince of Court Painters' and Wilde's 'The Portrait of Mr W. H'”, in Clements \& Higgins 2010, 117-134, at 117. According to Kelvin, Pater's 'portraits' were followed by those of Wilde's ("The Portrait of Mr W. H.”, 1889, and The Picture of Dorian Gray, 1891), Joyce's (Portrait of the Artist as a Young Man, 1916) and T. E. Eliot's (cf. his poem "Portrait of a Lady", 1917). 
has been connected to the fact that portraiture in general achieved more cultural capital from the mid-nineteenth century. ${ }^{58}$ Photography and its capacity for commodification plays a central role in this development: "Victorian and early modernist culture were saturated with popular photographic portraits, images that were ubiquitous and virtually classless, and that created for themselves an overwhelming presence". ${ }^{59}$ Norman Kelvin argues that Walter Pater and Oscar Wilde, due to photography's lack of uniqueness and aura, "rejected photography for their literary work, recognizing on some level the all-too manifest status of photographs as mass commodity". ${ }^{60}$ In his short story "The Real Thing" Pater's contemporary, the Anglo-American novelist Henry James, spelled out why this was the case: photography merely represents the surface of things; real art, however, investigates what is underlying the surface, it interprets life. Pater was apparently critical of the new mechanical-chemical visual medium, thus its meteoric rise may have been the impetus for his verbal portraits. Pater's literary portraits, while hovering between fiction and history, reflect critically the crisis of portrait painting and the problematic status of portrait photography which had gained dramatically in influence during the second half of the nineteenth century. Stephen Bann has argued that Pater's texts, like Henry James's and unlike John Ruskin's Stones of Venice, demonstrate a "textual self-sufficiency" 61 and he conspicuously resists the use of cover pictures and illustrations. ${ }^{62}$ Instead, Pater's imaginary portraits as well as his essays are replete with verbal pictures, i.e. pictorial and ekphrastic descriptions which need to be visualised by the reader during the reception process.

It is true that Pater nowhere refers directly to the new visual medium of his time, photography, which it is likely he did not consider as an art form at all, merely a minor phenomenon of mass culture. During the early decades following its invention photography was indeed considered a documentary medium rather than an art; during the latter decades of the nineteenth century, however, many photographers insisted their work to be art just like painting. One of the English pioneers of photography, Julia Margaret Cameron (1815-1879), famous for her pictorial portraits of art-

58 Cf. Michael Bartram, The Pre-Raphaelite Camera. Aspects of Victorian Photography (London: Weidenfeld and Nicholson, 1985).

59 Kelvin 2010, 119. Interestingly, "the use of 'portrait' in a title of a work of fiction or poetry diminishes after the 1920s and seems non-existent today" (Kelvin 2010, 118).

60 Kelvin 2010, 120.

61 Cf. Stephen Bann, "Epilogue. On the Homelessness of the Image", Walter Pater and the Culture of the Fin-de-siècle: Comparative Criticism. Ed. E. S. Shaffer. 17 (1995): 123-128, at 123. As Stephen Bann has pointed out Pater's procedure contrasts sharply with Ruskin's "voracious accumulation of illustrative materials ... How Pater must have detested the sheer profusion and professionalism of Ruskin's illustrated publications!" (124).

62 Rippl 2005, 103-121. 
fully posed contemporaries such as Thomas Carlyle, Sir John Herschel and Alfred Tennyson, developed photography into an art form by making her portraits and tableaux vivants intentionally out of focus, thus conjuring up the interiority of her sitters. In a letter to Herschel (31 December 1864) she commented on her technique as follows:

[I] believe in other than mere conventional topographic photography - mapmaking and skeleton rendering of feature and form without that roundness and fulness of force and feature, that modelling of flesh and limb, which the focus I use only can give, tho' called and condemned as 'out of focus'. What is focus and who has a right to say what focus is the legitimate focus? My aspirations are to ennoble photography and to secure for it the character and uses of High Art by combining the real and the ideal and sacrificing nothing of Truth by all possible devotion to Poetry and beauty. ${ }^{63}$

While Kelvin and Bann have underlined Pater's textual self-sufficiency, other scholars have pointed out the parallels between Pater's work and photography. Julia Straub, for instance, has argued that Cameron's photographic aesthetic of externality and interiority, of visibility and invisibility can be juxtaposed with Walter Pater's complex concept of diaphaneity which has its origins in his essay "Diaphaneité", written in 1864 and published post-humously in 1894. Pater's concept of diaphaneity suggests "notions of fragile beauty and androgyny and resistance to attempts of categorization along conventional lines", 64 features which Cameron's photographs share. Like Pater's imaginary portraits, her photographic art is also steeped in an interest in mythology and tradition, something Helen Groth has called "anachronistic excesses". ${ }^{65}$ By highlighting the photographic qualities of Pater's ekphrasis of Mona Lisa, for instance his interest in light and not in colours, Juliane Vogel has convincingly argued the influence of photography on Pater's work. ${ }^{66}$ The latest debates on the interrelations between Pater's texts and photography clearly show that literature never simply denies and surpresses the impact of new media. As the history of the media demonstrates, specific characteristics of a medium, for instance literature, can only be reconstructed through a comparative analysis with other media: By negotiating its own place in the net-

${ }^{63}$ Helmut Gernsheim, Julia Margaret Cameron. Her Life and Photographic Works (Millerton: Aperture Found, 1975) 14.

64 Julia Straub, "Diaphanous Angels. Julia Margaret Cameron's and Walter Pater's Go-betweens”, Textus 21 (2008): 261-278, at 263.

65 Helen Groth, Victorian Photography and Literary Nostalgia (Oxford. Oxford UP, 2003) 7.

66 Juliane Vogel, "In der Bilderflucht. Walter Paters Imaginary Portraits", Poetik der Evidenz. Die Herausforderung der Bilder in der Literatur um 1900. Ed. Helmut Pfotenhauer, Wolfgang Riedel \& Sabine Scheider (Würzburg: Königshausen \& Neumann, 2005) 19-30, at 22-24. Vogel succinctly summarises: "Das Erwachen der bildenden Kunst am Eingang der frühen Neuzeit muss als ein fotografisches Ereignis inszeniert werden. Paters Renaissance tritt als ein Lichteffekt in die Kunstgeschichte ein” (24). 
work of media of its time, Pater's fiction (as well as his essays) collaborates and competes with other media which eventually leads to the development of new aesthetic strategies in the texts.

"Denys l'Auxerrois" (published in 1886 and for a second time in the 1887-collection of Imaginary Portraits) presents an imaginative reconstitution of antique Greek culture and its god Dionysus at a later period in Western cultural history and in a remote northern place. Its events take place around 1200, a time when - according to Pater - the Renaissance, i.e. the continuation of the Hellenic spirit and the reconciliation of Christianity with the religion of ancient Greece, set in. ${ }^{67}$ In his "Denys l'Auxerrois" the ancient god Dionysus returns to the French Gothic town of Auxerre as an organ-builder. From the very beginning of the text, one of the main characteristics of the pagan god Dionysus, the vine, is omnipresent in the setting: the thirteenth-century Auxerre is "a veritable country of the vine". ${ }^{68}$ The story runs as follows: When in a finely sculptured Greek stone coffin, probably used for a later Roman funeral, a "flask of lively green glass, like a great emerald" 69 is found by carvers, the subsequent mixing of the sediments of Roman wine with a fine old wine of Auxerre releases a "riotous and earthy heat of old paganism". ${ }^{70}$ A "sort of golden age seemed indeed to be reigning ... for a while, and the triumphant completion of the great church [of St. Étienne] [is] contemporary with a series of remarkable wine seasons", ${ }^{71}$ and a new spirit of freedom is abroad everywhere. The exceptionally hot nights start to be "noisy with swarming troops of dishevelled women and youth with red-stained limbs and faces, carrying their lighted torches over the vine-clad hills ... A shrill music, a laughter at all things" 72 is everywhere. Ecstasy had taken hold of

${ }^{67}$ Pater traces the Renaissance back to the end of the twelfth century, "far into the middle age itself, with its motives already clearly pronounced, the care for physical beauty, the worship of the body, the breaking down of those limits which the religious systems of the middle age imposed on the heart and the imagination" (Renaissance XXXII). In his essay on Pico della Mirandola, Pater continues: "An earlier and simpler generation had seen in the gods of Greece so many malignant spirits, the defeated but still living centres of the religion of darkness, struggling, not always in vain, against the kingdom of light. Little by little, as the natural charm of pagan story reasserted itself over minds emerging out of barbarism, the religious significance which had once belonged to it was lost sight of, and it came to be regarded as the subject of a purely artistic or poetical treatment. But it was inevitable that from time to time minds should arise, deeply enough impressed by its beauty and power to ask themselves whether the religion of Greece was indeed a rival of the religion of Christ." (Renaissance 20).

68 Pater, "Denys l'Auxerrois" 47.

69 Pater, "Denys l'Auxerrois" 50.

70 Pater, "Denys l'Auxerrois" 50.

71 Pater, "Denys l'Auxerrois" 51.

72 Pater, "Denys l'Auxerrois" 53. 
the people and nature produced an unknown abundancy ("It seemed there would be winter no more". ${ }^{73}$ However, things start to change when after a long journey to the south - Denys returns in a querulous mood, replaces his diet of spring water and fruit with wine and brown meat, and strange "motiveless misdeeds" 74 start to happen. Denys now reminds the wise monk Hermes of the pagan wine god who is famous for his two natures, "difficult or impossible to harmonize". ${ }^{75}$ Suddenly the life of the community changes, women drown their newborn babies, a kind of degeneration and coarseness comes over people and nature. Denys who is finally charged with murder and sorcery, manages to escape to a nearby monastry. After the consecration of the organ he built there, the personification of winter is hunted blindfold through the streets in a pageant and Denys himself "as if mechanically, falls again into the chief place". ${ }^{76}$ When the rough haircloth scratches his lip deeply, and a long trickling of blood is seen upon his chin, a mad rage comes over the spectators and the

\begin{abstract}
...pretended hunting of the unholy creature became a real one, which brought out, in rapid increase, men's evil passions. The soul of Denys was already at rest, as his body, now borne along in front of the crowd, was tossed hither and thither, torn at last limb from limb. The men stuck little shreds of his flesh, or, failing that, of his torn raiment into their caps; the women lending their long hairpins for the purpose. The monk Hermes sought in vain next day for any remains of the body of his friend. Only, at nightfall, the heart of Denys was brought to him by a stranger, still entire. It must have long since mouldered into dust under the stone, marked with a cross, where he buried it in a dark corner of the cathedral aisle. ${ }^{77}$
\end{abstract}

This is the violent end of the story about Dionysus' return at a later time and in a northern place. ${ }^{78}$ The extreme cruelty of Denys' violent death can be explained by referring to René Girard's anthropological model of sacrificial violence which he developed in his book Violence and the Sacred. He states what Pater shows: "the slightest outbreak of violence can bring about a catastrophic escalation ... there is something infectious about the spectacle of violence". ${ }^{79}$ As the feeling of unity had been disturbed by former Dionysian outbursts of many of Auxerre's inhabitants, the killing of Denys at the end of Pater's story may be interpreted as a reconciliatory sacrifice ending quarrels and restoring order. Within an anthropological or ethnological framework, Denys-Dionysus' violent death

\footnotetext{
73 Pater, “Denys l'Auxerrois” 53.

74 Pater, "Denys l'Auxerrois" 55.

75 Pater, "Denys l'Auxerrois" 56.

76 Pater, "Denys l'Auxerrois" 61.

77 Pater, "Denys l'Auxerrois" 61.

78 Of course Pater's “Denys l'Auxerrois" reminds its readers of Euripides' “The Bacchae," the story of a festival which does not end well either.

79 René Girard, Violence and the Sacred. Trans. Patrick Gregory (Baltimore: Johns Hopkins UP) 1986, 8.
} 
is a necessary outlet for Auxerre's community to find peace again. The catharsis such acts of violence allow is socially regenerative and cohesive; it reinforces the social fabric. In ancient myth Dionysus was also dismembered (by Titans), but was subsequently reintegrated and reanimated by Rheia, Zeus' mother (cf. below). What is astonishing in Pater's imaginary portrait is the fact that the ancient god seems to have lost all his former power, he is no longer the god who dies and then returns renewed: Pater's protagonist Denys is neither resurrected nor is there any sign of his return.

The 'imaginary portrait' is the appropriate genre for Pater because it allows him to exchange exact historical facts for the greater immediacy of fictitious legends. Imaginary portraits such as "Denys l'Auxerrois" are Pater's literary way of dealing with the cultural past; they are ideal texts to understand his concept of cultural memory, continuity, transculturality and intermediality. Two paintings, "Bacchus" and "Saint John the Baptist" which Pater both ascribed to Leonardo ${ }^{80}$ are excellent examples for demonstrating this: Pater was fascinated because "Saint John the Baptist" has a "strange likeness to the Bacchus which hangs near it" in the Louvre. ${ }^{81}$ But not only do St. John and Bacchus show remarkably similar countenances and gestures, the protagonist of Pater's "Denys l'Auxerrois", too, is closely related to the prototype, the ancient god Dionysus. While in his "Leonardo" essay Pater delivered an ekphrastic portrait of Leonardo's Mona Lisa, in his "Denys l'Auxerrois" such descriptions of specific paintings are not found; instead notional ekphrases, i.e. ekphrases of works of arts which do not exist, play a central role. ${ }^{82}$

Dionysus fascinated Pater who in addition to his imaginary portrait also wrote an essay about him in $1876 . .^{83}$ The title of this essay, "A Study of Dionysus. The Spiritual Form of Fire and Ice", refers to the double birth of the god: Dionysus or Bacchus (also 'Bromios', "the roaring, the raging, the boisterous") is the son of Zeus and Semele. Semele, the daughter of Thebe's king Cadmos, (prompted by the jealous Hera) makes Zeus promise to come to her in his true likeness. Reluctantly he does so but of course her mortal frame cannot bear his divine splendour and she dies. Hermes, another of Zeus' sons, then rescues Dionysus, who is an embryo, by sewing him into Zeus' thigh. In due time he is born a second time, ringed with water and dew. Hera, Zeus' jealous wife, later has Dionysus dismembered by Titans. However, Dionysus-Zagreus (i.e. "the dismem-

${ }^{80}$ Recent research shows that the picture of Bacchus was not done by the master himself, but by a pupil belonging to his school.

81 Pater, Renaissance 76.

82 For a discussion of 'notional ekphrasis' cf. John Hollander, The Gazer's Spirit. Poems Speaking to Silent Works of Art (Chicago: U of Chicago P, 1995) 4 and $7 \mathrm{ff}$.

83 Walter Pater, "A Study of Dionysus. The Spiritual Form of Fire and Dew", Greek Studies. Pater. $2^{\text {nd }}$ ed. (London: Macmillan, 1901) 9-52. 
bered") is reintegrated by Rheia, Zeus' mother, reanimated and then looked after by Persephone. After a sojourn in India, he returns and starts to be worshipped all over the ancient world, becoming one of the twelve most important Olympian gods. In Athens he was also the god of the theatre, and tragedies were performed in his honour. Dionysus was celebrated as a dying and resurrected god of vegetation who only later became the God of vines. Pipe music and wine arouse an enthusiasm in man which allows him to reunite with Nature and to remove other barriers typical of individuals and their historical experience. If Dionysus enters a human being, he or she becomes imbued with godlike qualities and will develop unprecedented talents. Dionysus, the hunter and the hunted, is a god of duality, as he brings life and death, pain and pleasure, ecstasy and grief, a god who dies and then returns renewed - an aspect of the myth Pater concentrated on in his essay on Dionysus. He combines great gentleness with extreme cruelty. As the Dionysus mysteries are closely connected with dismemberment and the eating of flesh and wine, Dionysus is seen as the precursor of Christ, a connection which is made in St. John's Gospel. ${ }^{84}$

Apart from linking Dionysus with Demeter and portraying him as the god of vegetation ${ }^{85}$ and enthusiasm (Dionysus as deliverer, Eleutherios), ${ }^{86}$ Pater stresses two things: Firstly, the dual nature of this god, who "has his alternations of joy and sorrow, of struggle and hard-won triumph", 87 who is hunter and hunted in one person as the Orphic version has it $(\mathrm{Pa}$ ter refers to the Dionysiaca by Nonnus, a writer of the fourth century). ${ }^{88}$ While artists of the Italian Renaissance have treated Dionysus "in his joy, as an embodiment of that glory of nature to which the Renaissance was a return", 89 Pater is more interested in a melancholy and sorrowing Dionysus, as he has rarely ever been depicted elsewhere. A notable exception is Simeon Salomon's Bacchus, which was in the exhibition of the Royal Academy of $1868,{ }^{90}$ and which Pater praised in his essay "A Study of

84 Cf. Jochen Hörisch, "Im Zeichen des Weinstocks: Dionysos und Christus”, Brot und Wein. Die Poesie des Abendmahls (Frankfurt am Main: Suhrkamp, 1992) 57-70.

85 Pater, "A Study of Dionysus" 13.

${ }^{86}$ Pater, "A Study of Dionysus" $18 \mathrm{f}$.

87 Pater, "A Study of Dionysus" 40.

88 Pater, "A Study of Dionysus" 51.

89 Pater, "A Study of Dionysus" 41.

90 As Ulrike Stamm has rightly pointed out Pater also derived his knowledge about myth from later works of art such as paintings of Tizian, of Tintoretto or Simeon Salomon ("Ein Kritiker aus dem Willen der Natur": Hugo von Hofmannsthal und das Werk Walter Paters [Würzburg: Königshausen \& Neumann, 1997] 257). Salomon was a painter connected with the group of Pre-Raphaelites, well known to Pater. His painting of a rather melancholic Bacchus which was shown in the Royal Academy Exhibition in 1868 might also have influenced Pater in his depiction of the vine god as melancholic being in the second 
Dionysius" in 1876. Secondly, Pater tests the reuniting powers of Dionysus, but (cf. below part IV) deviates from the Romantics and Friedrich Nietzsche. ${ }^{91}$

In his imaginary portrait "Denys l'Auxerrois" Pater not only carefully integrates many of the features of the pagan god Dionysus in the protagonist Denys who brings ecstasy, enthusiasm and unheard-of artistic talents, but also madness and destruction to the people of Auxerre; he also uses an ancient mode, namely ekphrasis, to refer back to classical myth. The story has a rather lengthy introduction with a post-Romantic narrator approaching Auxerre in the manner of an art-historian or connoisseur on his grand tour through Europe, delivering long, meticulous descriptions of nature, landscape, architecture and works of art. Auxerre is said to be of "a beauty specific - a beauty cisalpine and northern, yet at the same time quite distant from the massive German picturesque of Ulm, or Freiburg, or Augsburg, and of which Turner found the ideal in certain of his studies of the rivers of France, a perfectly happy conjunction of river and town being of the essence of its physiognomy". ${ }^{92}$ This interest in art history can be found throughout the text which is full of architectural ekphrases of cathedrals and churches of Troyes, Sens and Auxerre, ${ }^{93}$ towns situated in the Loire valley, which was a region of France Pater loved. Architectural ekphrases have a long tradition starting in antiquity (cf. Statius' Silvae with its descriptions of villas, ${ }^{94}$ or Procopius' famous decription of the

part of his imaginary portrait "Denys l'Auxerrois". Cf. also J. B. Bullen, "Pater and Contemporary Visual Art", Cahiers victoriens et édouardiens 68 (2008): 87-103. According to Bullen, Pater had "his first sight of Solomon's controversially homoerotic study entitled Bacchus at the Royal Academy" (89). Cf. also Stefano Evangelista, “A Revolting Mistake: Walter Pater's Iconography of Dionysus”, Victorian Review 34.2 (2008): 201-218.

91 The German Romantic poet Hölderin, for instance, believed that Dionysus' uniting powers were able to heal processes of atomisation and the "Sinnkrise" of modern societies. Cf. Manfred Frank, "Brauchen wir eine 'Neue Mythologie?"”, Kaltes Herz. Unendliche Fahrt. Neue Mythologie (Frankfurt am Main: Suhrkamp, 1989) 93-118, at $115 \mathrm{ff}$. According to the Romantics the European Enlightenment was responsible for the death of myth, which is why they proposed a new mythology of reason (Frank 1989, 98 and 100, trans. G.R.): "Die Stiftung einer neuen Mythologie unter Bedingungen des von der Aufklärung besiegelten Todes Gottes - diese Obsession wird sich als eine der mächtigsten in der literarischen, gesellschaftstheoretischen und philosophischen Debatten des 19. und 20. Jahrhunderts erweisen" (Frank 1989, 95).

92 Pater, "Denys l'Auxerrois" 45f.

93 In 1894, Pater wrote an essay called "Notre-Dame d'Amiens", and he also left an unfinished manuscript of an essay called "Notre-Dame de Troyes". These essays owe a lot to Ruskin's book on The Bible of Amiens (1885), although Pater never admitted it. Cf. Bernard Richards, "Pater and Architecture", Pater in the 1990s. Ed. Laurel Brake \& Ian Small (Greensboro: ELT P, 1991) 189204.

94 Statius, Silvae. trans. Heinz Wissmüller (Neustadt: Schmidt, 1990) 48-53. 
Hagia Sophia). The description of Troyes is of page-length, as are the ones of Sens and Auxerre. The educated traveller displays his artistic knowledge by hinting at stylistic peculiarities like "varieties of the Pointed style down to the latest Flamboyant", "wildly elegant Gothic-on-stilts", "grotesque" at Troyes, ${ }^{95}$ and "a more chastened temper" at Sens where everything is "cool and composed, with almost English austerity", like the "first growth of the Pointed style in England - the hard 'early English' at Canterbury", 96 as the architect was educated in the schools at Sens. Even nature itself is described with the eyes of an art historian:

The [river] Yonne, bending gracefully, link after link, through a never-ending rustle of poplar trees, beneath lowly vine-clad hills, with relics of delicate woodland here and there ... has all the lightsome characteristics of French river-scenery on a smaller scale than usual, and might pass for the child's fancy of a river, like the rivers of the old miniature-painters, blue, and full to a fair green margin. ${ }^{97}$

Claus Uhlig has called such a way of perceiving nature, landscape and architecture as if figured through the eyes of a painter (here a miniaturepainter) "secondary vision". 98 The landscape is not seen with an innocent eye, but with the eye of the connoisseur, who notices its picturesque quality while comparing it to existing pictures of the region. Pater admired the beauty of the landscape, the descriptions of which were influenced by J. M. W. Turner's landscape painting in his three separate Rivers of France series of which only two were actually published, Wanderings by the Loire (1833) and Wanderings by the Seine (1834). ${ }^{99}$ It is this secondary vision which makes the landscape with its buildings so charming and attractive for the narrator. Auxerre, the central setting of "Denys l'Auxerrois", is:

... the broad framework of vineyard sloping upwards gently to the horizon, with distant white cottages inviting one to walk: The quiet curve of river below, with all the riverside details: the three great purple-tiled masses of Saint Germain, Saint Pierre, and the cathedral of Saint Étienne, rising out of the crowded houses with more than the usual abruptness and irregularity of French building. Here, that rare artist, the susceptible painter of architecture, if he understands the value alike of line and mass, of broad masses and delicate lines, has 'a subject made to his hand'. ${ }^{100}$

Long descriptions of visual impressions and allusions to other media, namely painting, drawing and sculpture are typical of all of Pater's texts. They metamorphose his texts into verbal pictures, luring their readers to

\footnotetext{
95 Pater, "Denys l'Auxerrois" 46.

96 Pater, "Denys l'Auxerrois" 47.

97 Pater, "Denys l'Auxerrois" 47.

98 Uhlig 1974, 218.

99 Ascari 1999, 104.

100 Pater, "Denys l'Auxerrois" 47.
} 
visualise before their inner eye what is being displayed. Naturally, Pater's readers need a certain amount of knowledge of art history and architecture in order to realise the whole semantic impact of his texts. The intense visuality of Pater's texts is always connected with memories of former visual impressions, especially those engendered by works of art. Hence Pater's pictorial descriptions of landscapes are to be discussed in an intermedial framework, even if only the single medium of text is present. His descriptions of specific pictures or sculptures (which may or may not exist) are (notional) ekphrases which aim at visual effects and enargeia (i.e. vivid description which appeals to the inner eye of his reader). ${ }^{101}$ Etymologically the Greek term ekphrasis means simply 'to speak out' or 'to show clearly and completely'; the OED records the word as first used in English in 1715. According to James A. W. Heffernan's widely accepted definition, ekphrasis is "the verbal representation of visual representation". ${ }^{102}$ While (notional) ekphrasis as a literary descriptive mode is at least as old as Homer's depiction of Achilles's shield in Book 18 of the Iliad, it was rhetoricians of late antiquity who actually developed a 'theory' of description they called ekphrasis (in Greek) or evidentia (in Latin) (sometimes also hypotyposis or descriptio). This 'theory' consisted of a set of rules about how to describe things properly. Description was considered as a mode of speaking which - by aiming at enargeia - was able to bring absent objects before the listener's inner eye. According to Quintilian it served to rouse the listener's affections by making him/her an eyewitness of the things and events being described. Ruth Webb has pointed out the fact that the term 'ekphrasis' has undergone a severe narrowingdown of its meaning: while for ancient rhetoricians any kind of description (be it of persons, objects, places or time) that was 'enargetic' was labelled ekphrasis, today only those descriptions are counted as ekphrases which actually evoke a visual work of art. ${ }^{103}$ During its long history there were times when ekphrasis was widely used, and other times when it was nothing but an ephemeral literary or rhetorical phenomenon. Nineteenthcentury realist literary texts as well as those of the later aestheticist period

101 Rippl 2005, for the picturesque roots of Walter Pater's as well as Henry James's verbal pictures of landscapes cf. esp. 121-148.

102 Heffernan 1993, 2.

103 Ruth Webb has pointed out that "Quintilian explains both how to produce enargeia in a speech and what its effects upon the listener should be. In the Institutio oratoria $(6.2 .29-32)$ he explains that enargeia is produced when the orator uses his own power of imagination to conjure up a scene in his mind. This exercise in visualization ensures that his language will spark a mental impression in the mind of his audience" ("Ekphrasis Ancient and Modern: The Invention of a Genre”, Word \& Image. Ed. Mario Klarer. 15.1 [January-March 1999]: 718 , at 13). The verbal techniques for achieving enargeia range from a plain and blunt enumeration to the most meticulously detailed depiction of objects, including all kind of stylistic intricacies. 
such as Pater's are replete with pictorial descriptions and (notional) ekphrases.

In "Denys l'Auxerrois" the story starts with an ekphrastic description of a curious fragment of stained glass the narrator comes across in a bricà-brac shop at Auxerre. He assumes that it might have come from the cathedral itself, but "it presented a figure not exactly conformable to any recognised ecclesiastical type". ${ }^{104}$ From the priest of a neighbouring village he learns that the same figure can be found in an old tapestry, the description of which is again an ekphrasis, this time a very long one:

In both were the same musical instruments - pipes, cymbals, long reed-like trumpets. The story, indeed, included the building of an organ ...; whereas in certain of the woven pictures the hearers appear as if transported, some of them shouting rapturously to the organ music. A sort of mad vehemence prevails, indeed, throughout the delicate bewilderments of the whole series - giddy dances, wild animals leaping, above all perpetual wreathings of the vine, connecting, like some mazy arabesques, the various presentations of one oft-repeated figure, translated here out of the clear-coloured glass into the sadder, somewhat opaque and earthen hues of the silken threads. The figure was that of the organ-builder himself, a flaxen and flowery creature, sometimes well-nigh naked among the vine-leaves, sometimes muffled in skins against the cold, sometimes in dress of a monk, but always with a strong impress of real character and incident from the veritable streets of Auxerre. What is it? Certainly, notwithstanding its grace, and wealth of graceful accessories, a suffering, tortured figure. With all the regular beauty of a pagan god, he has suffered after a manner of which we must suppose pagan gods incapable. It was as if one of those fair, triumphant beings had cast in his lot with the creatures of an age later than his own, people of larger spiritual capacity and assuredly of a larger capacity for melancholy. ${ }^{105}$

This extended ekphrasis of the tapestry is the condensed version of the story Pater's narrator presents to the readers. The tapestry and the stained glass fragments help this nineteenth-century traveller to detect his version of the thirteenth-century events as they might have happened. However the notional ekphrasis is a highly imaginative one which does not give any details of the overall design, the colour pattern and the relation of the parts of the tapestry in a way that the readers can visualise it. Rather it dramatises the encounter with a visual work of art and hence focuses on "the act of interpreting visual art and translating images into words". 106 Pater's ekphrasis, although it adds a static element to the text, triggers the

104 Pater, "Denys l'Auxerrois" 48.

105 Pater, "Denys l'Auxerrois" 49.

106 Cf. Kenneth Daley, "Pater's Auxerre Tapestry", in Clements \& Higgins 2010, $85-101$, at 85 . Daley argues that Pater's ekphrastic image of the tapestry is associated with the feminine and the homosexual: "As the representation of a silent tapestry telling a tale of suffering and torture, I suggest that the portrait belongs to a particular subgenre of the ekphrastic tradition associated with Ovid, the myth of Philomela, and the "voice of the shuttle" (Daley 2010, 86). 
narrative which it frames. While Pater's imaginary prowess manifests itself in the abundant intermedial transgressions of texts, and while he is aware of the power of images, "the unrelenting narrative thrust of ekphrasis works to subdue the presence of the visual medium". ${ }^{107}$ With such gestures of paragone Pater claims that narrative is more important than the visual with its static qualities and that the verbal can doubtlessly compete with the deluges of images produced by mechanical media such as photography.

In his Greek Studies, a collection of his essays on ancient Greek art and culture which came out the year following his death in 1895, Pater expressed his admiration for the earliest examples of ekphrasis we know in Western literature, namely Homer's vivid ekphrases which are full of narrative energy. ${ }^{108}$ According to Pater they testify to the poet's powers of imagination: ${ }^{109}$

There are in Homer two famous descriptive passages in which this delight in curious metalwork is very prominent; the description in the Iliad of the shield of Achilles, and the description of the house of Alcinous in the Odyssey. The shield of Achilles is part of the suit of armour which Hephæstus makes for him at the request of Thetis; and is wrought of variously coloured metals, woven into a great circular composition in relief, representing the world and the life in it. The various activities of man are recorded in this description in a series of idyllic incidents with such complete freshness, liveliness, and variety, that the reader from time to time may well forget himself, and fancy he is reading a mere description of the incidents of actual life. ...

Such descriptions, however, it may be said, are mere poetical ornament, of no value in helping us to define the character of an age. But what is peculiar in these Homeric descriptions, what distinguishes them from others at first sight similar, is a sort of internal evidence they present of a certain degree of reality, signs in them of an imagination stirred by surprise at the spectacle of real works of art. ${ }^{110}$

As Martine Lambert-Charbonnier succinctly summarises, ekphrasis is "a model of composition, since in the Greek Studies Pater admires Homer's ekphraseis for their effect of wholeness - they convey a full image of ancient life within the imaginary spaces of the shield and of the house". ${ }^{111}$ For Pater lively, fresh ekphrases are not "mere poetical ornament", but help him to "define the character of an age". They are central in Pater's work for several reasons: Due to their referential function they produce and support the illusion of reality, testify to ancient life and animate the reader to come up with lively associations. In addition they express the

107 Daley 2010, 88.

108 Walter Pater, “The Beginnings of Greek Sculpture”, Greek Studies. Pater. $2^{\text {nd }}$ ed. (London: Macmillan, 1901) 187-250.

109 Cf. Martine Lambert-Charbonnier, "Poetics of Ekphrasis in Pater's 'Imaginary Portraits"” in Brake, Higgins \& Williams 2002, 202-212, at 212.

110 Pater, "The Beginnings of Greek Sculpture" at 193 and $198 \mathrm{f}$.

111 Cf. Lambert-Charbonnier 2002, 202. 
writer's imagination as well as the imagination of Pater's narrators, the susceptible nineteenth-century travellers and connoisseurs. These narrators come across ancient stained glass fragments, tapestries, paintings, monuments and sculptures and they invest these tacit objects with a prosopopoeial voice: The beauty and vividness is not in the objects, but rather in the lively imagination of Pater's beholders. Ekphrases link Pater's fiction to his art criticism; and it is the power of the ancient genre of ekphrasis to conjure up the past (classical antiquity, the Middle Ages, the nineteenth century), to make it speak to the readers. Pater not only writes about classical antiquity, he does so by returning to an ancient classical mode of writing, ekphrasis.

According to Pater who is a Romanticist in this respect, art follows the principle of Anders-streben and tries to keep the boundaries between the different art forms open:

... although each art has thus its own specific order of impressions, and an untranslatable charm, while a just apprehension of the ultimate differences of the arts is the beginning of aesthetic criticism; yet it is noticeable that, in its special mode of handling its given material, each art may be observed to pass into the condition of some other art, by what German critics term as Anders-streben - a partial alienation from its own limitations, through which the arts are able, not indeed to supply the place to each other, but reciprocally to lend each other new forces. ${ }^{112}$

However, by acknowledging the differences between the arts as well as their limitations in his essay on "The School of Giorgione" quoted above, Pater also makes it clear that he was well acquainted with Lessing, who in the Laokoon (1766) tried to divide the two arts, poetry and painting, according to their semiotic differences. ${ }^{113}$ While Pater does not suffer from what Irving Babbitt in his New Laokoon (1910) called "eleutheromania" ${ }^{114}$ references to visual art (and to music for that matter) help him to involve his readers by creating a more intense and peculiar atmosphere words alone could not evoke. They authenticise the fictitious world, and support Pater in condensing the atmosphere and the impressions he wants to convey. "Denys l'Auxerrois" is a good example of such a condensation. What Pater praised in Homer's ekphrasis of Achilles' shield, namely " $[\mathrm{t}] \mathrm{he}$ various activities of man are recorded in this description in a series of idyllic incidents with such complete freshness, liveliness, and variety, that

112 Pater, Renaissance 85.

113 Gotthold Ephraim Lessing, Laocoön. An Essay on the Limits of Painting and Poetry, trans. E. A. McCormick (Baltimore: Johns Hopkins UP, 1984). Cf. Margaux Poueymirou, "Walter Pater's Anders-Streben: As Theory and as Practice”, in Brake, Higgins \& Williams 2002, 63-85.

114 Irving Babbitt, The New Laokoon. An Essay on the Confusion of the Arts (London: Constable-London, 1910). 196. "Eleutheromania" names the disrespect for medial differences between the arts, which may lead to their distortion and perversion. 
the reader from time to time may well forget himself, and fancy he is reading a mere description of the incidents of actual life" holds also true for Pater's imaginary portrait at the end of which the reader needs to be reminded of the fact that what was delivered was nothing but the narrator's ekphrastic interpretations of a tapestry and some fragments of stained glass.

\section{Pater's Greece}

According to Pater, mankind's cultural memory gathers all the cultural harvests from ages far apart - nothing is ever lost. ${ }^{115}$ This is the reason why he thought of works of art as archaeological sites that need to be excavated. His scholar-artist, characterised by a special susceptibility and inspired by archaeology and excavation, important activities in the nineteenth century, is able to make the palimpsest of culture more legible by illuminating its diverse layers. Unsurprisingly metaphors from archaeology and excavation play a central role in Pater's texts, ${ }^{116}$ many of which deal with former cultures, especially with pagan Greek cults and ancient myths such as those of Demeter, Persephone and Dionysus. ${ }^{117}$ But unfortunately,

115 Just a few decades after Pater's death, T. S. Eliot in his essay "Tradition and the Individual Talent" (1919) will refer to archaeology as he - like other modernists - is interested in deep structures of culture such as myths, rites and traditions. When we consider Pater's efforts to re-discover lost cultural traditions, it becomes obvious how much the modernists owe him. It was Pater after all who first hoped to overcome the modern experience of fragmentarization by dealing with cultural continuities, an idea which Eliot picked up. T.S. Eliot's famous sentence from the end of The Waste Land (1922, in T. S. Eliot. The Waste Land and Other Poems [London: Faber \& Faber, 1990] 21-49), “These fragments I have shored against my ruins" (41), hints at his idea of an active appropriation of tradition and the notion of a simultaneous presence of all ages in the critical consciousness. The poet is connected to the whole literature of the past, he is in charge of a rejuvenation, reactivation and reorganisation of the cultural memory (cf. T.S. Eliot, "Tradition and the Individual Talent", Eliot, Selected Essays [London: Faber \& Faber, 1963] 13-22). Eliot tries to neutralise typical modern experiences such as transitoriness, fragmentation and oblivion with aesthetic ideals such as completeness and a systematic concept of tradition. But whereas Walter Pater's concept of culture and tradition is one of wistful reminiscence, T. S. Eliot and Ezra Pound came to understand tradition also as a burden, which is why Pound's guiding principle became "Make it new!"

116 Cf. Barbara Korte, “The Reassuring Science’? Archäologie als Sujet und Metapher in der Literatur Britanniens", Poetica 32.1-2 (2000): 125-150.

117 Cf. Anne-Florence Gillard-Estrada, "The Resurrected Youth and the Sorrowing Mother: Walter Pater's Uses of the Myths of Dionysus and Demeter", Cahiers victoriens et édouardiens 68 (2008): 155-180. Cf. also Wolfgang Iser, “Art and Myth”, in Iser 1987, 105-127, for a discussion of Pater's notion of myth and its differences to that of other scholars of the time. 
Pater's influential Greek Studies which shaped the view of Greek antiquity held by famous writers such as Hugo von Hofmannsthal and Hilda Doolittle - is often neglected in discussions of modernist aesthetics. ${ }^{118}$ Ezra Pound and T. S. Eliot followed Friedrich Nietzsche who considered Aeschylus to be the epitome of the tragic era of the Greeks, while Euripides was associated with the romantic age, with the decadence movement and the works of Pater, who - similarly to Aby Warburg, and in contrast to the idealised notion of Greece of many of his contemporaries such as Cardinal Newman and Matthew Arnold - stressed the dark side of ancient, prehistoric Greek culture, with its counter-traditions, its conflicts and violence in his Greek Studies, in his historical novel Marius the Epicurean (published in 1885) and in his lectures on Plato and Platonism (published in 1893).

In his mythopoetical imaginary portrait "Denys l'Auxerrois" (but also in "Apollo in Picardy", 1893) Pater fathomed how far the resurrected ancient god would indeed be able to disturb the Christian order and whether he could really bring unity, totality and a second golden age to medieval French communities. As we have seen, the regenerative influence on physical, religious, aesthetic and intellectual life of Pater's pagan god did not last long. Whereas Nietzsche articulated his "faith in a future rebirth of Hellenic antiquity" 119 and saw myth as a means to renew man and the world, Pater's pagan god brings confusion and division. ${ }^{120}$ For Pater myths are an aesthetic phenomenon, which - just like poetry - help to explain and order the world we live in. If myth is a "poetic rendering of the world" and art the inheritor of myth, it needs artists and poets to keep myth alive. Pater's view of myth is a genetic one prevalent in Victorian England. According to Pater's concept (which is based on Karl Otfried Müller's The History and Antiquities of the Doric Race, published in English in $1830^{121}$ ), myth undergoes three stages: firstly, it is a natural phenomenon which is then turned into a human figure, and finally is transformed into a higher ethical principle. But Pater's view of myth also

118 Cf. Stamm 1997, 257. Eileen Gregory in her book H. D. and Hellenism: Classic Lines (Cambridge: Cambridge UP, 1997) discusses Pater's influence on Hilda Doolittle.

119 Nietzsche 98.

120 Wolfgang Iser pointed out an important difference between Pater and Nietzsche. Whereas Nietzsche in his The Birth of Tragedy used "the myth of Dionysus to construct his theory of the eternal return, Pater's study of Apollo shows the impossibility of activating these mythical forces in the historical world. Nietzsche believed that myth could renew man and the world, but Pater's gods, when they return to the historical world, bring chaotic confusion and division. For Nietzsche myth was a moral power; for Pater it was an aesthetic phenomenon" (Iser 1987, 126).

121 German original 1820 (vol. 1) and 1824 (vols. 2-3). Cf. John Smith Harrison, "Pater, Heine, and the Old Gods of Greece", PMLA 39 (1924): 655-686. 
differs significantly from that of his contemporaries. While they hold on to an optimistic utopian belief in cultural progress, a belief influenced by the ideas of the enlightenment and best summarised by Cardinal Newman's and Matthew Arnold's definitions of Greek culture and classical polytheism as "gay and graceful", ${ }^{122}$ Pater provides a comprehensive dark ritual prehistory for his contemporaries' Greece of grace, repose and serenity. Late nineteenth-century archaeology and excavation

... involved the physical repossession of the ancient past, a past conceived of in material terms: statues, graves, relics. And as Pater turned towards the material past of the ancient Greeks that was now ever more rapidly being uncovered by archaeology, he simultaneously turned away from those idealist versions of the distant past that such aesthetic students as Johann Winckelmann and such linguistic resurrectionists as Pater's colleague, the famous comparative philologist Friedrich Max Müller had raised up to reassure the Victorians. ${ }^{123}$

Pater's ideas about cultural history and his investigations into the darker and violent side of ancient Greek culture involved a keen interest in the materiality of ancient statuary and culture and were closely allied with the new results of comparative archaeology and mythography of the late nineteenth century. As prehistoric archaeology reached far back into the human past to a time when primitive men had hunted and cooked their food not just in the Amazon region and the Australian Bush, but also in Devon, ${ }^{124}$ and as this material culture of early man "coincided so strikingly with the material culture of existing "savages", the widespread "Victorian faith in their nobly high-minded ancestors among the Greeks" was discredited as was their blind belief in the progress of civilization. ${ }^{125}$ Whereas for Newman and Arnold "Greece is invested with a Winckelmannian calm and leans towards the statuesque, a sunlit Apollonianism ... Pater was far more alive ... to the 'other' tradition - roughly, the Dionysian - in Greek art and religion". ${ }^{126}$ According to David J. DeLaura, Pater's view of Greece is more complex than Arnold's rather academic Hellenism, and it is also better informed, and more historically authentic:

By adding the Dionysian tradition to the Apollonian, Pater was able, for polemical purposes, to advance his 'enriched' view of Greek religion as a conscious alternative to a played-out Christianity. Pater's greater knowledge allowed him

122 John Henry Newman, “An Essay on the Development of Christian Doctrine." 1845. Cf. Pater, Renaissance 128.

123 Linda Dowling, "Walter Pater and the Matter of the Self", Die Modernisierung des Ich, ed. Manfred Pfister (Passau: Richard Rothe, 1989) 64-73. 67.

124 Cf. John W. Burrow, "The Uses of Philology in Victorian Britain", Ideas and Institutions of Victorian Britain: Essays in the Honour of George Kitson Clark, ed. Robert Robson (New York: Barnes \& Noble, 1967) 180-204, at 202.

125 Dowling 1989, 67.

126 David J. DeLaura, Hebrew and Hellene in Victorian England (Austin: U of Texas P, 1969) 171f. 
to challenge Arnold's occasional high evaluation of medieval Christianity by suggesting that Greek popular religion, undervalued by Arnold, had permanent elements of depth and complexity which simply reappear in the Middle Ages. ${ }^{127}$

For Pater, Johann Joachim Winckelmann was the incarnation of a scholar wistfully trying to regain past times. But as Winckelmann's famous formula of "edle Einfalt und stille Größe" ("noble simplicity and tranquil grandeur") is blind to the other side of Greek art that dealt with conflict and evil, it is but a partial description of Greek antiquity: "In it the eye is fixed on the sharp, bright edge of high Hellenic culture, but loses sight of the sombre world across which it strikes". ${ }^{128}$ Pater's own and independent view of antiquity can best be extracted from his interpretation of Dionysus and of Apollo (in "Apollo in Picardy") as twofold gods, including not only a bright, but also a dark and destructive side. Whereas Nietzsche conceives of the Apollonian as an opposition to the Dionysian, Pater locates artistic creativity in the figure of Dionysus himself. For Pater, Dionysus is much more complex than he seems to be in Nietzsche's thinking. Pater, for instance, finishes his "A Study on Dionysus" (Dec. 1876) by referring to the orphic cult of Dionysus which concentrates on the figure of the suffering Dionysus and the notion of the twofold Dionysus became central in his "Denys l'Auxerrois", where the protagonist in the second phase turns into a cruel and melancholy being. Although Pater developed a dualistic concept of the gods Dionysus and Apollo, the gods themselves are divided. In his essay "The Marbles of Aegina", ${ }^{129}$ which again relies on Karl Otfried Müller's work, Pater presents a differentiation between two opposing tendencies in Greek culture and art that can be traced throughout Greek history and which he calls the "centrifugal" and the "centripetal." 130 Whereas the "centrifugal, the Ionian, the Asiatic" is a tendency

flying from the centre ... throwing itself forth in endless play of undirected imagination; delighting in brightness and colour, in beautiful material, in changeful form everywhere, in poetry, in philosophy, even in architecture and its subordinate crafts. In the social and political order it rejoices in the freest action of local and personal influences; its restless versatility drives it towards the assertion of the principles of separatism, of individualism, - the separation of state from state, the maintenance of local religions, the development of the individual in that which is most peculiar and individual in him. ${ }^{131}$

This centrifugal force is the Dionysian principle of culture. Its opposite, the Apollonian or Dorian principle is relevant for Europe. It is a realiza-

127 DeLaura 1969, 177. De Laura's study is a thorough investigation in Pater's indebtedness to and criticism of Arnold.

128 Pater, Renaissance 128.

129 Written in April 1880, published in Pater's Greek Studies. $2^{\text {nd }}$ ed. (London: Macmillan, 1901) 251-268.

130 Pater, "The Marbles of Aegina" 252.

131 Pater, "The Marbles of Aegina” 252. 
tion of a certain inward, abstract, intellectual ideal, aiming at "order, a sanity, a proportion in all work" and reflecting "the inward order of human reason, now fully conscious of itself". ${ }^{132}$ This centripetal tendency "links individuals to each other, states to states, one period of organic growth to another, under the reign of a composed, rational, self-conscious order, in the universal light of the understanding". ${ }^{133}$ While this temper is best traceable in the Dorian race, Pater does not deny that the Apollonian principle can appear elsewhere. ${ }^{134}$

Pater emphasised the double nature of Greek culture and its countertraditions in order to show that culture is a continuum and Christian religion therefore not unique. Even when it comes to the question of sorrow, Christianity had its precursor in Greek cult. The myths which most fascinated Pater were those dealing with grief. Thus his interest in the myths of Demeter-Persephone and Dionysus which express tragic experiences regarded by Pater to be the core of Greek myth and art: Demeter is a divine grieving mother and it is out of the sorrows of Dionysus that Greek tragedy develops. Such myths help man to transcend the burdensome experience of death and, by doing so, allow for a more intense and complete life. Greek culture is the basis for Pater's humanism and a model for possible ways of harmonising the disparate forces of man's nature. Critics today underline the importance of ancient Greek material culture, in particular "artefacts excavated in 1858 by Charles Thomas Newton at a small cave sanctuary dedicated to Demeter at the ancient Greek port of Cnidus (on the couthwest coast of Turkey)" for Pater's "disturbing Hellenism" and his idea of cultural continuity between modern Europe and ancient Greece, ${ }^{135}$ which after all were not exclusively based on textual sources, but rather on a thoroughly integrative, comprehensive and imaginative approach to Greek culture and its history. ${ }^{136}$

132 Pater, "The Marbles of Aegina" 251.

133 Pater, "The Marbles of Aegina" 253.

134 The fact that Pater and Nietzsche in their respective studies on Apollo and Dionysus were interested in the same questions can be explained by their reliance on the same source, namely Karl Otfried Müller's Die Dorier (published in 1820 and 1824 and translated into English in 1830). Helen Young suggests that Pater borrowed his centripetal-centrifugal terms from William Wallace's The Logic of Hegel (1774), cf. Helen Young, The Writings of Walter Pater (Lancaster: Bryn Mawr College, 1933).

135 Shawn Malley, "Disturbing Hellenism: Walter Pater, Charles Newton, and the Myth of Demeter and Persephone", in Brake, Higgins \& Williams 2002, 90106, at 90. Malley also points out that "Newton's most famous student, Jane Harrison, used [Newton's] materials in her exposé of the irrational under-texture of Greek cults" (93).

136 Cf. Christian J. Emden's two recent studies on Nietzsche's concepts of history and classical scholarship which provide useful insights into the cultural history of antiquity and the history of classicism in Germany and England and hence are relevant also for students of Walter Pater: Nietzsche on Language, Con- 
Over the last decades scholars of Victorian literature, modernism, gender and art history have investigated Walter Pater's complex literary texts and essays from new angles. Due to the intense cross-cultural, intermedial and interdisciplinary nature of his work Walter Pater remains a topical writer for today's students of English literature. The intermedial quality of his texts in particular, i.e. his ekphrastic references to sculpture, painting and music as well as his conspicuous silence with respect to photography, provides an important research field for those who deal with questions concerning visuality, the role of images and the interrelations of the media in late Victorian and early modernist culture. Also, Pater's notions of cultural memory and continuity, of tradition and transcultural influence - to which his understanding of myth testifies - are of great importance. As it is, Pater reappropriates classical antiquity, ancient gods and myths in a very modern way, i.e. he does not reverently save and pass on the old tales; he rather modernises them by adding variations, thus helping to conserve their vividness and assign them contemporary relevance. Future work on the history of culture will certainly have to intensify the contextualisation and comparison of Pater's ideas on myth, culture, cultural memory, history and tradition to those of his contemporaries and later scholars whose viewpoints he anticipated, such as Friedrich Nietzsche, Sigmund Freud, Jane Harrison and the "Cambridge school" of classical scholarship (which focused on the social background of ancient Greek religion, ritual and myth), but also Walter Benjamin ${ }^{137}$ and Aby Warburg.

BERN

GABRIELE RIPPL

sciousness, and the Body (Chicago: U of Illinois P, 2005), and Friedrich Nietzsche and the Politics of History (Cambridge: Cambridge UP, 2008).

137 Cf. Kit Andrews, "Walter Pater and Walter Benjamin: The Diaphanous Collector and the Angel of History", in Brake, Higgins \& Williams 2002, 250-260. 